\title{
EVALUATING URBAN SPRAWL AND LAND-USE CHANGE USING REMOTE SENSING, GIS TECHNIQUES AND HISTORICAL MAPS. CASE STUDY: THE CITY OF DEJ, ROMANIA
}

\author{
Anna-Hajnalka KEREKES \\ Babeș-Bolyai University, Faculty of Geography, 5-7 Clinicilor Street, 400006, Cluj-Napoca, Romania, \\ e-mail: annakrks@yahoo.com
}

Mircea ALEXE *

Babeș-Bolyai University, Faculty of Geography, Department of Physical and Technical Geography, 5-7 Clinicilor Street, 400006, Cluj-Napoca, Romania, e-mail: mircea.alexe@ubbcluj.ro

Citation: Kerekes, A.-H., \& Alexe, M. (2019). Evaluating Urban Sprawl and Land-Use Change Using Remote Sensing, Gis Techniques and Historical Maps. Case Study: The City of Dej, Romania. Analele Universităţii din Oradea, Seria Geografie, 29(2), 52-63. https://doi.org/10.30892/auog.292106-799

\begin{abstract}
The aim of this paper is to analyse, using GIS and remote sensing techniques, the land use/cover change of the city of Dej, in order to explore the spatial and temporal characteristics and the consequences of urbanization trends of the past 250 years. We used a wide range of data, including historical maps and Landsat images from 1984 to 2017. In order to identify the land-use change, we used supervised classification and change detection methods. Analysing the obtained data, we could conclude the fact that, between 1763 and 1990, the area was characterized by a significant urban sprawl and land-use change, due to the economic development and political views (the urban border area increased from $1.2 \mathrm{~km} 2$ to $13.72 \mathrm{~km} 2$ ), but after 1990, the suburbanization process has begun, due to the economic failure, having a $13.85 \%$ built-up area increase towards S-SE and $\mathrm{N}$ direction, constrained by hydrological and geomorphological factors.
\end{abstract}

Key words: remote sensing, land-use and cover change, change detection, GIS, satellite imagery, historical maps

$$
* \quad * \quad * \quad * \quad * \quad *
$$

\section{INTRODUCTION}

Remote sensing data covers large areas and it's characterized by a high temporal and spatial frequency; remote sensing can provide historical time series data; therefore, it became widely used with success in monitoring urban sprawl and land-use cover changes (Xiao et al., 2006; Stefanov et al., 2001). Landscape dynamics is an important issue in remote sensing and digital change detection, and can be analysed by using multi-temporal and multi-spectral satellite imagery (Rawat and Kumar, 2015). By land-use change, we mean a process by which anthropic factors transform 
the natural landscape; they are usually non-linear and can threaten people with vulnerability (Kasperson et al., 2017). According to Lakshmana, 1993, land-use is the result of an accumulation of individual decisions, in order to satisfy some objectives within some set of land-use constraints or attractions; moreover, the growth of the land can also depend on the historical development, importance and attraction of the investigated area. Mapping land-use/cover change at local/regional scales can be used for different applications, like land planning strategies or hazard mitigation works (Reis, 2008).

To understand the consequences of the environmental changes, we need to use up-to-date and accurate data (Giri et al., 2005; Shalaby and Tateishi, 2007). With remote sensing techniques, the monitoring of these changes becomes possible. In order to extract change information from satellite data, we need to use effective and automated change detection techniques (Roy et al., 2002; Shalaby and Tateishi, 2007). By integrating remote sensing with GIS techniques, it becomes possible to analyze and classify different patterns during a long period of time, to efficiently exploit factors that cause land-use change and to understand the evolution trends of the urban area (Fichera et al., 2017). The urbanization is an inevitable and a widespread process, due to economic development and rapid population growth, which causes loss land-use and cover change, as it follows: loss of forest areas and arable lands, vegetation cover decline, built-up area expansion. (Lopez et al., 2001; Shalaby and Tateishi, 2007; Dewan and Yamaguchi, 2009).

There are various publications regarding the change analysis of urban areas: Chowdhury, 2003; Fang et al., 2005; Yuan et al., 2005; Gatrell and Jensen, 2008; My et al., 2009; El Garouani et al., 2017. These studies are important, because they promote a sustainable urbanization and they also illustrate the interaction between people and urban environments in which they live (Gatrell and Jensen, 2008).

In remote sensing, a variety of techniques have been developed in order classify different landscape components (Ozesmi and Bauer, 2002): unsupervised classification, supervised classification, PCA (Principal Component Analysis), Fuzzy Classification (Lu et al., 2004; Butt et al., 2015). The most widespread types of classifications are the following: supervised classification, PCA and Fuzzy Classification (Butt et al., 2015). Also, there are many change detection methods, from which the pre- and post-classification method was widely used (Dewan and Yamaguchi, 2009).

Therefore, the aim of this study is to evaluate, using remote sensing and GIS techniques, the land cover/use change and urban sprawl of the city of Dej, Romania, between 1763 and 2017, using multi-temporal satellite imagery and historical maps (The Military Surveys of Austrian Empire, The $1^{\text {st }}, 2^{\text {nd }}$ and $3^{\text {rd }}$ Military Mapping Survey of Austria-Hungary; different Romanian historical maps, between 1916-1959 - "Plan Director de Tragere"; sources: mapire.hu; geospatial.org). We selected the study area for analysis, because of its particular historical, geomorphological and hydrographical characteristics: active water erosion, land instability phenomenon and water level fluctuations, social and economic changes, especially after 1990, therefore, we could observe how these constraining factors affected the evolution of the city of Dej for approximately 250 years.

\section{STUDY AREA}

The study area, the municipality of Dej, has a population of 33497 citizens according to the 2011 census and has a surface of $109 \mathrm{~km}^{2}$.

From a geographical point of view, the city is situated within the central part of Transylvania, at the confluence of the Someșul Mic and Someșul Mare Rivers (figure 1), also being situated at the intersection between the $47^{\circ} 05^{\prime} 12^{\prime \prime} \mathrm{N}$ parallel and the $23^{\circ} 48^{\prime} 19^{\prime \prime} \mathrm{E}$ meridian, at $57 \mathrm{~km}$ away from Cluj-Napoca.

The city of Dej, from a geological and geomorphological point of view, is distinguished by large terraces, massive hills, with a wide range of land instability phenomenon and a highly developed hydrographic network, characterized by linear and vertical erosions (Ilovan and Papp, 2007). The city is located in a depressional area of water clusters, where Someșul Mic, Someșul 
Mare, Valea Codrului, Valea Olpretului, Valea Ungurașului, Valea Ocnei, Valea Chiejdului Rivers meet, resulting a flattened meadow, prone to floods and water level fluctuations (Plan Urbanistic General al Municipiului Dej, Memoriu General, 2005). Therefore, this area became very active in terms of erosional processes, eutrophication and sedimentation. These characteristics contributed, mostly to the modification of land-use structure and spatial evolution of the city.

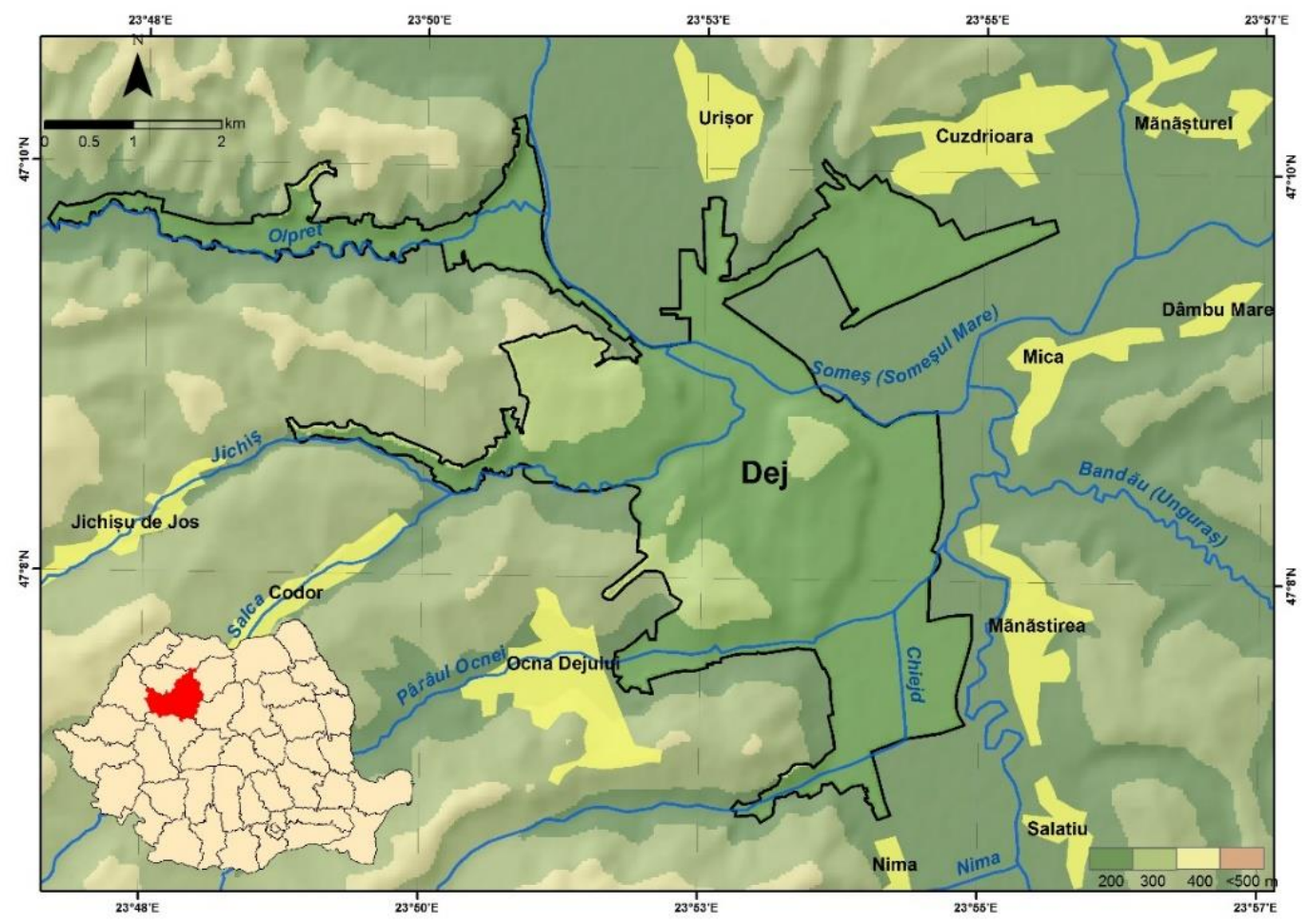

Figure 1. The geographic position of the city of Dej

The severity of many floods determined the deviation and drainage of some of the Someș River arms. After the damage of the 1970 floods, the urban planning strategy of the city was reorganized and a new and higher embankment was constructed near the river bed.

\section{SPATIAL DATABASE AND METHODOLOGY}

In order to realise land-use change and urban sprawl analysis, the acquired data must be adequate and precise. The spatial database contains cloud-free satellite imagery (Landsat 5 MSS, Landsat 7 TM, Landsat 8 OLI), historical maps and vector shapes (mapire.hu, geo-spatial.org) (table 1).

In order to emphasize the structure of the land use, we used multi-temporal imagery from different periods of time (Landsat 5 from 1984 July, Landsat 7 TM from 1993 July, Landsat 8 OLI from 2017 July).

This imagery was pre- and post-processed using ERDAS 2014 software. Geometric corrections were applied on all the satellite imagery of the Dej city area. The resolution of the satellite images is $30 \mathrm{~m}$.

The four historical maps were georeferenced and digitized using ArcMap 10.6 (figure 2). The maps were converted into Stereographic 1970 projection. While digitizing the maps and 
satellite imagery, we created the following shape files: urban area borders, hydrography, forests. These shape files were used to calculate statistics in different periods, so we could determine the rate of urban sprawl and the effects of this process on the environment.

Table 1. Spațial database

\begin{tabular}{|c|c|c|}
\hline Name & Type & Source \\
\hline The $1^{\text {st }}$ Mapping Survey of Austria-Hungary 1763-1787 & Raster and vectorized & mapire.eu \\
\hline The $2^{\text {nd }}$ Military Mapping Survey of Austria-Hungary 1806-1869 & Raster and vectorized & mapire.eu \\
\hline The $3^{\text {rd }}$ Military Mapping Survey of Austria-Hungary 1869-1887 & Raster and vectorized & mapire.eu \\
\hline „Planurile Directoare de Tragere” 1916- 1959 & Raster and vectorized & mapire.eu \\
\hline Landsat 5, Landsat 7, Landsat 8 (1984, 1993, 2017) & Raster and vectorized & USGS \\
\hline
\end{tabular}

Using historical maps to extract information and data form the pre-satellite ages is relatively simple, even though, there could exist some accuracy errors, because the maps were digitized on different accuracy-levels, but the influence of this variability minimal because of the coarse time scales used in the present (Xiao et al., 2006).
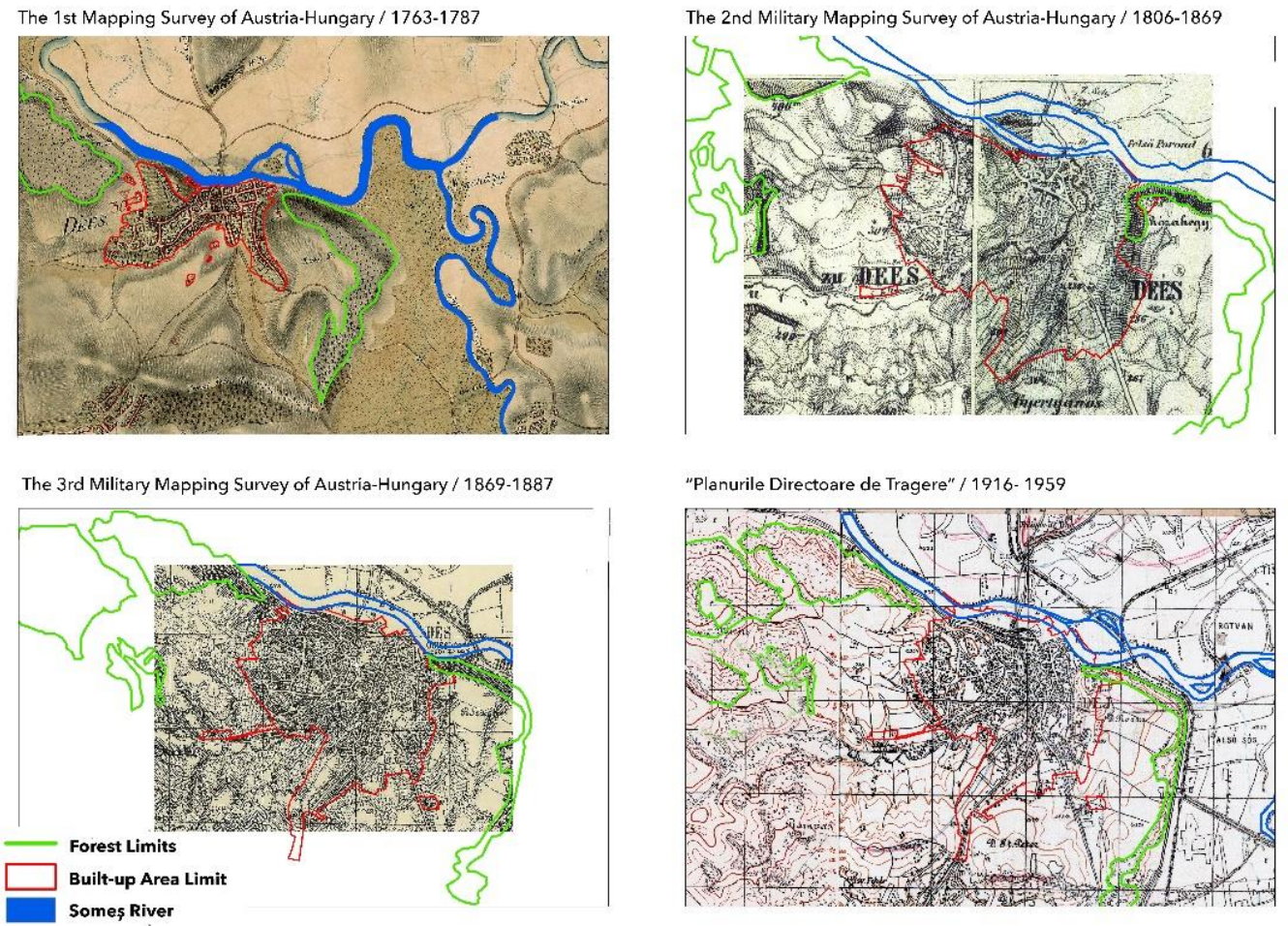

Figure 2. The georeferenced historical maps

\section{Image pre-processing}

The most important step is the image pre-processing, in order to realize an adequate change detection. In this study, we used geometric corrections and image enhancement.

Geometric registration is required to remove random distortions (variation in sensor system attitude and altitude) present in remote sensing data (Rogan and Chen, 2004). The Landsat images were geometrically corrected, obtaining a $<0.5$ pixel route main square error (RMSE). The RMSE between any two dates must be less than 0.5 pixel to become an acceptable error (Lunetta and Elvidge, 1998; Shalaby and Tateishi, 2007). Post classification 
method does not require radiometrical or normalized corrections before the images are used for change detection (Warner and Campagna, 2009).

Image enhancement is a process in which we can change the pixel values in order to emphasize the information within an image, and to increase the apparent distinction between different features (Abd El-Kawy et al., 2011). In this study, we used contrast stretching in order to visually analyze different features (Abd El-Kawy et al., 2011). Some classes can be spectrally confused and they cannot be separated by supervised classification, therefore, it becomes necessary visual interpretation (Shalaby and Tateishi, 2007).

\section{Image classification}

We applied the maximum likelihood supervised classification on the satellite images (Landsat 5, 1984; Landsat 7, 1993; Landsat 8, 2017 (figure 3) using training samples. The objective of the image classification is to automatically categorize within an image into land cover classes (Lillesand and Kiefer, 1994; Shalaby and Tateishi, 2007). The area was classified into four land-use categories: arable land, vegetation, hydrography and built-up area.

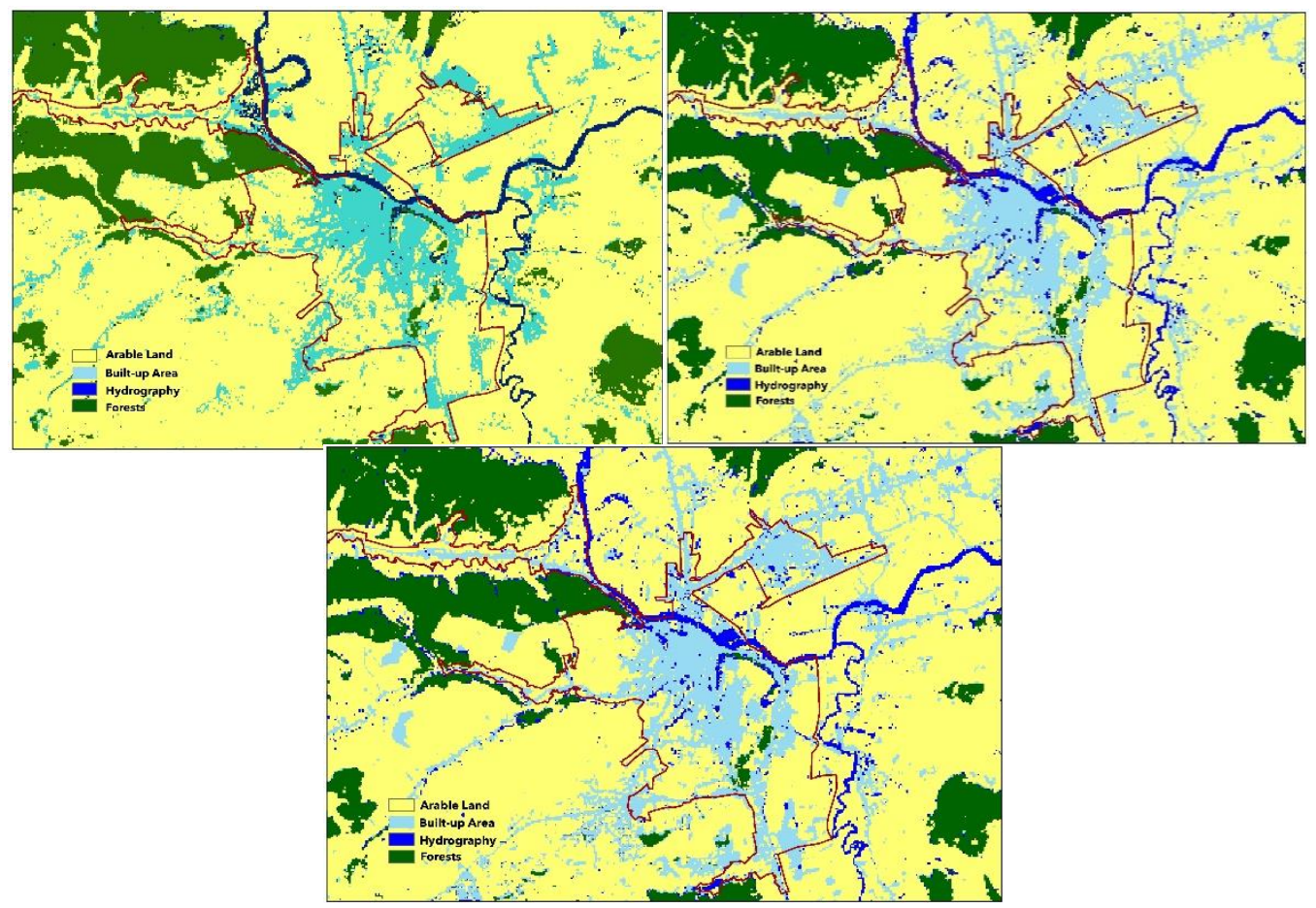

Figure 3. The classified Landsat images

(left: Landsat 5, 1984; right: Landsat 7, 1993; middle: Landsat 8, 2017)

An accuracy assessment was applied on the classified images. It is important to perform accuracy assessment for individual classification in order to verify if the results are useful (Owojori and Xie, 2005). The classification accuracy assessment was realised by generating an error (confusion) matrix, which implies the calculation of the overall accuracy (representing a ratio between the total number of correctly classified and the total number of reference pixels) and Kappa coefficient (Cohen, 1960; Liu et al., 2007; Olofsson et al., 2014). The Kappa coefficient, evaluates the level of agreement between the observed and predicted classes; the value of the coefficient varies between 0 and 1 (Hogland et al., 2013; Foody, 2002). 
The Kappa coefficient was calculated based on the equation:

$$
k=\frac{N \sum_{i=1}^{r} x_{i i}-\sum_{i=1}^{r}\left(x_{i+} x_{+i}\right)}{N^{2}-\sum_{i=1}^{r}\left(x_{i+} x_{+i}\right)}
$$

where:

$\mathrm{N}=$ the total number of observations (pixels) in the confusion matrix;

$\mathrm{r}=$ the number of rows in the confusion matrix;

$\mathrm{Xii}=$ the number of observations (pixels) in the $\mathrm{i}$ row and $\mathrm{i}$ column;

$\mathrm{Xi}+=$ marginal sum of observations (pixels) of row $\mathrm{i}$;

$\mathrm{X}+\mathrm{i}=$ marginal sum of observations (pixels) of column $\mathrm{i}$

\section{Change detection}

Change detection was applied using the post-classification method between 1984-1993, 1993-2017, based on the satellite imagery presented above.

The post-classification technique provides "from-to" change information, therefore, any landscape transformation can be easily observed and mapped (Yuan et al., 2005). This method allows to determinate the difference between independently classified images and it is the only method that allows the calculus of every pixel-change (Fichera et al., 2017). In order to realise the change detection analysis, we used the cross-tabulation method (Tabulate area tool in ArcGIS 10.6).

\section{RESULTS}

Before realising the analyses, we tested the validity of the classified images, using the Kappa coefficient presented above. The values of the Kappa coefficient, according to Congalton, 1991, can be divided into 3 groups: values higher than 0.80 means strong agreement between the classified data and reference data; values between $0.40-0.80$ represent a moderate agreement; values below 0.40 depict a weak agreement.

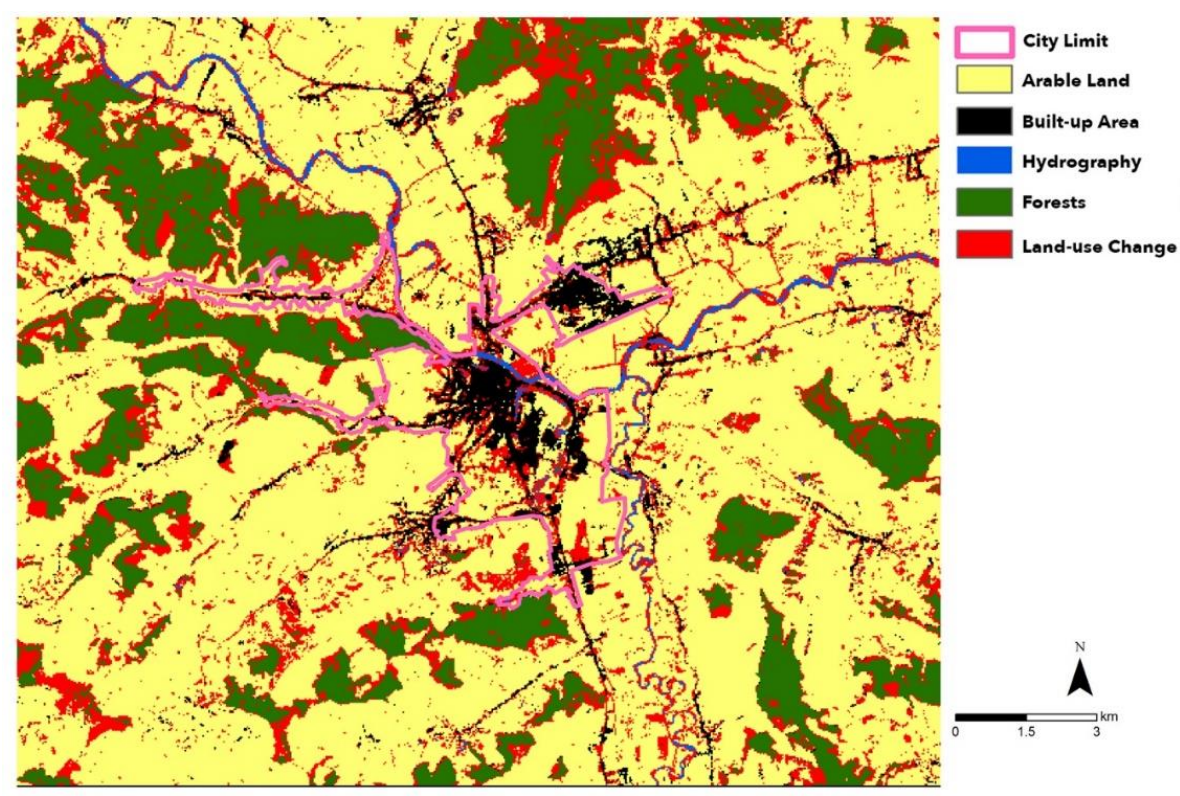

Figure 4. Change detection results (1984-2017) 
The accuracy assessments of the 1984, 1993 and 2017 classified images were realised generating 250 random points from each image, having the following results: 0,801 (1983), 0,823 (1993) and 0,890 (2017). These results represent a high agreement between the classified and reference data, therefore, we could made further analyses.

The results of the change detection analysis can be observed on figure 4 . With the help of the cross-tabulation tool, we could clearly calculate the growth of the built-up area by $13.85 \%$ (many new constructions appeared between 1984 and 2017).

We could also observe that, between 1984-2017, a slight decrease in vegetation $(4.66 \%)$, and we could remark the modification of wetlands and hydrography (a decrease of $4.17 \%$ caused by river draining and the river bed modification) (table 2, figure 5).

Table 2. The modification of the land-use in percentage between 1984 and 2017

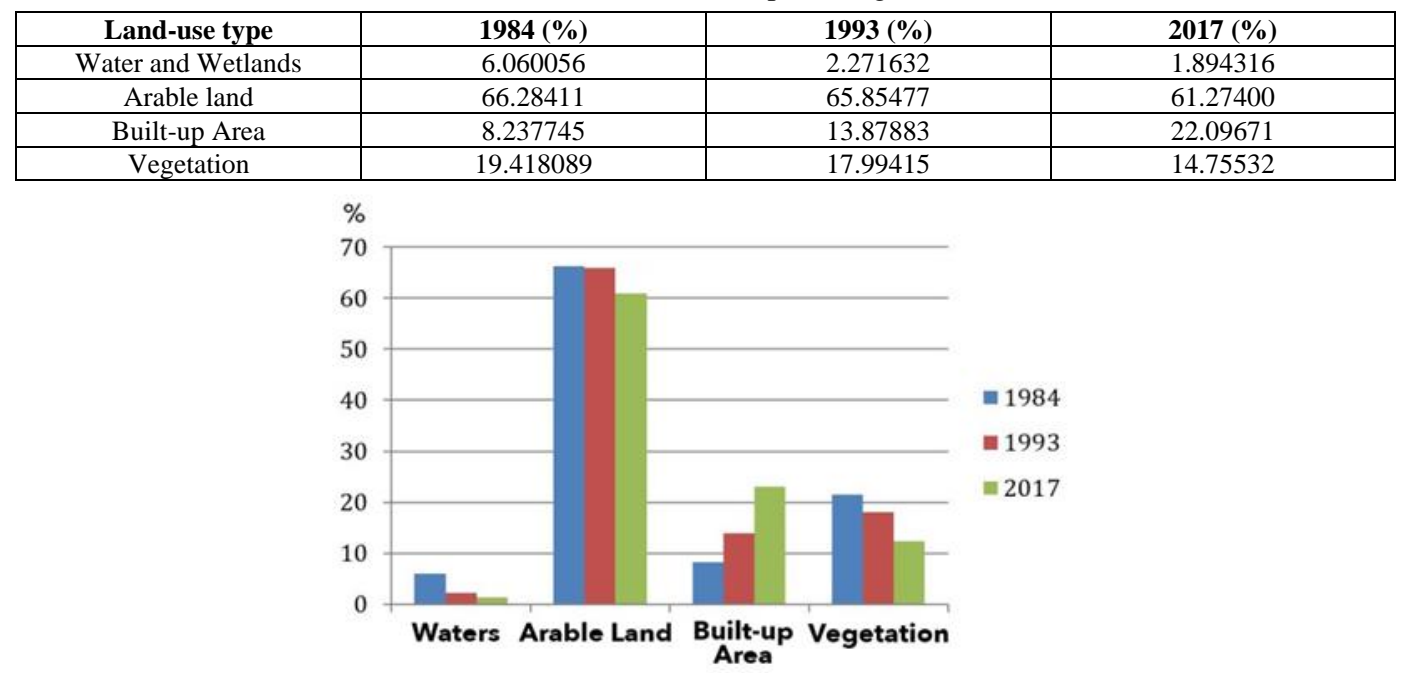

Figure 5. The land-use change tendency between 1984 and 2017

To explain the results of the change detection, we analysed the satellite imageries and the historical maps from the past 250 years. We observed the fact that, the city of Dej is characterized by some high and low stages.

When comparing the historical maps and the satellite imageries, we concluded the fact that, the urban border area was modified gradually between 1763 and 1984 , increasing from $1.2 \mathrm{~km}^{2}$ to $13.72 \mathrm{~km}^{2}$ (table 3 ). This increase is due to the following facts:

a) In the $18^{\text {th }}$ century, the city of Dej, due to its particular position (salt resources near the surface; economic potential; intersection of three river corridors) became favourable to the appearance of communication crossroads; these factors ensured the development of a market town (Ilovan and Papp, 2017; Rüsz, 2003). This increase can be observed on the $1^{\text {st }}$ and $2^{\text {nd }}$ Mapping Survey of Austria-Hungary; the urban border area has increased by $116.66 \%$ (figure 6 , table 4) and the forest lands decreased by $47.29 \%$ (table 4 ).

b) In 1881, the railway infrastructure was set up, therefore, Dej became an important railway connection knot between the northeast, northwest, and the south of Transylvania, hence it helped the economic development of the city (Ilovan and Papp, 2007). This modification can be observed on the $3^{\text {rd }}$ Military Mapping Survey of Austria-Hungary by the increase of the urban border surface with $20.76 \%$ (figure 6 , table 4 ).

c) After the Second World War, new food units, wood- and raw material processing industries appeared, therefore, increasing the attraction of the city (many people from nearby 
villages migrated in Dej due to the communist regime) (Ilovan and Papp, 2007). As a consequence, the urban border area has increased significantly by $281.11 \%$, and the forest lands had decreased dramatically by $82.05 \%$ (figure 7 , table 4 ).

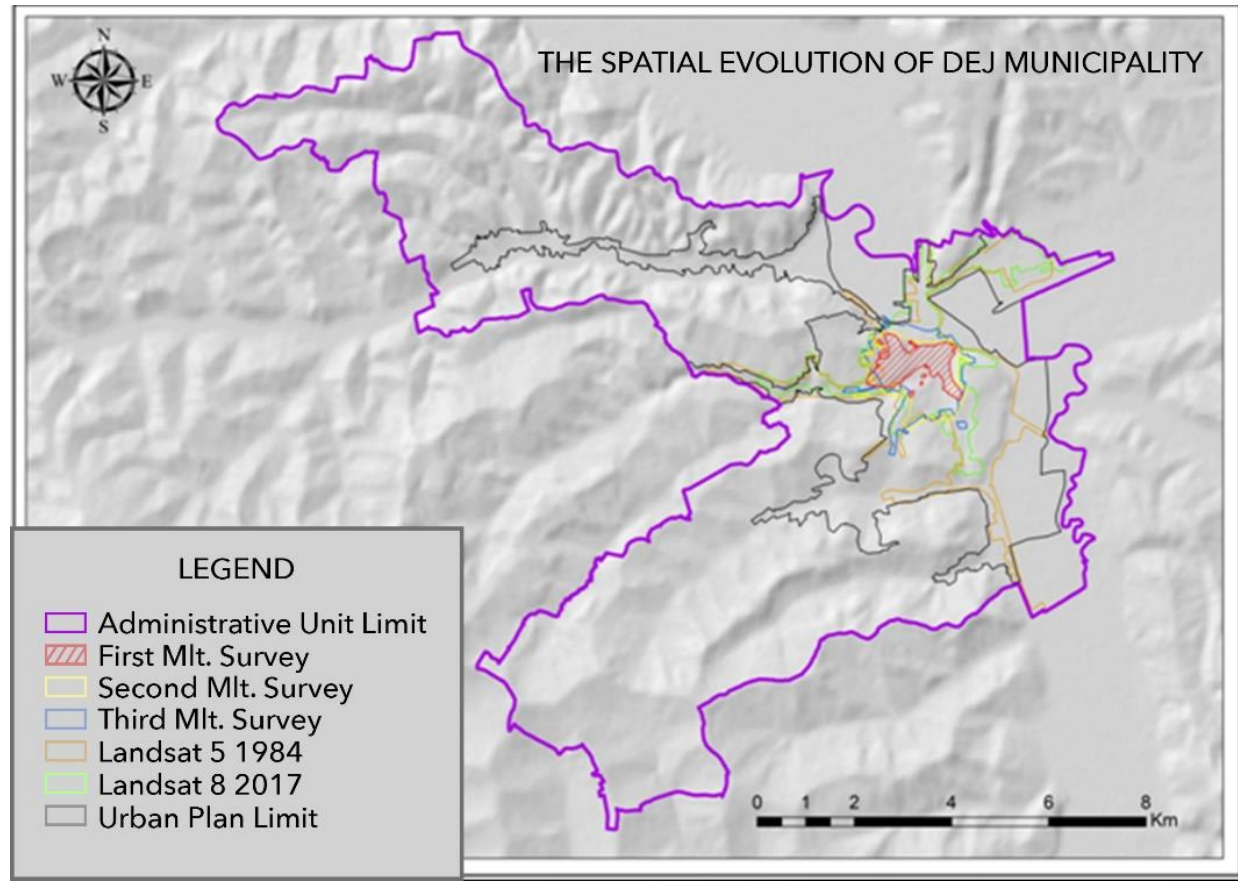

Figure 6. The urban-border area increase over 250 years

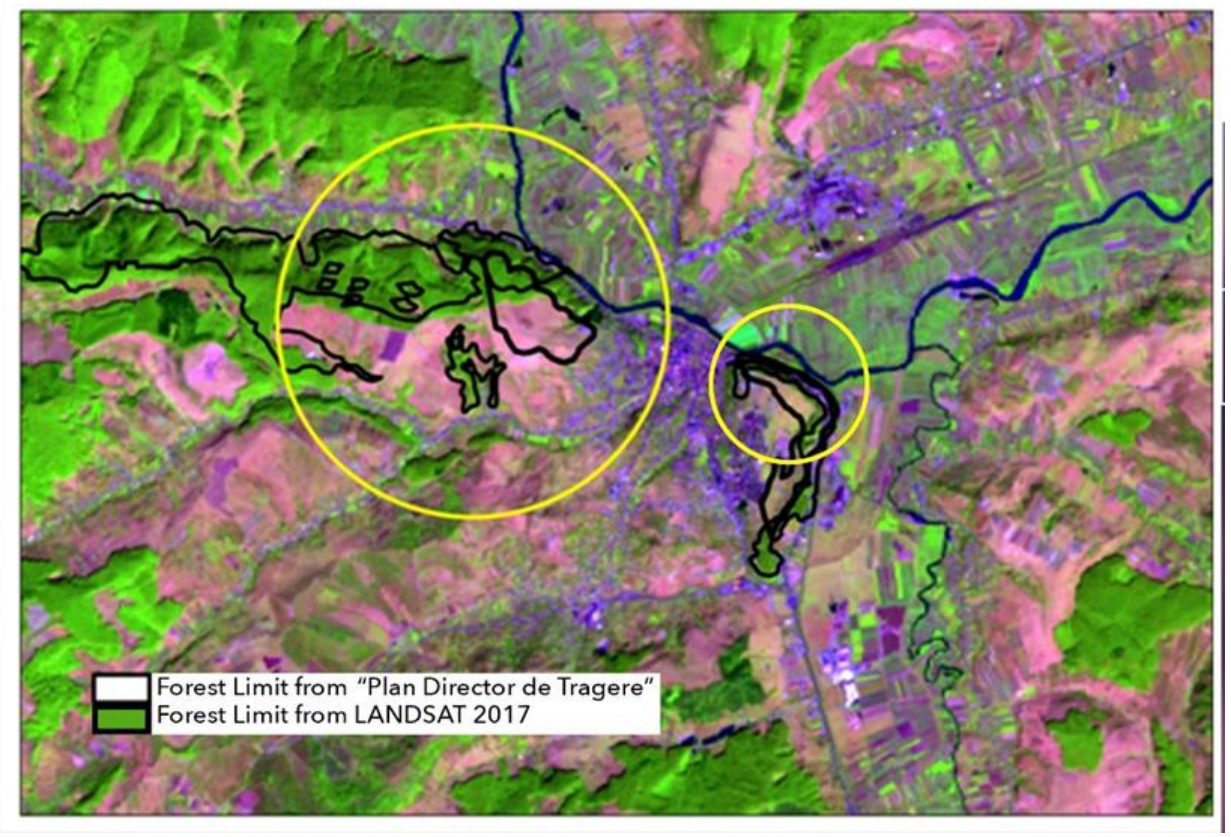

Figure 7. The dramatic decrease of forests 
After 1990, the suburbanization process of the city was emphasized using supervised classification and the post-classification method, the built-up area increased by $13,85 \%$ towards SSE and N communication roads, near the city limit; the urban border surface has increased by $49.27 \%$ due to the new political, social and economic context introduced into the Romanian society; the old industrial units were privatised and were still using old, polluting equipment, therefore, they couldn't sustain the market for selling products, hence having low productivity (Benedek and Bagoly, 2005; Ilovan and Papp, 2007). Due to the higher attraction of other neighbouring spaces (due to the domination of agricultural activities and industries), like Cuzdrioara, Căşeiu, and Jichişu de Jos and Mica, the suburbanization process of Dej city has begun (Ilovan and Papp, 2007). In this period, due to a low industrial profile, the forest areas were represented by stagnation (table 3 ).

Table 3. The surface modification of the urban border's area and forests between 1763 and 2017

\begin{tabular}{|c|c|c|c|c|c|c|}
\hline $\begin{array}{c}\text { Land-use } \\
\text { type }\end{array}$ & $\begin{array}{c}\text { The } 1^{\text {st }} \\
\text { Mapping } \\
\text { Survey of } \\
1763-1787\end{array}$ & $\begin{array}{c}\text { The } 2^{\text {nd }} \\
\text { Mapping } \\
\text { Survey of } \\
1806-1869\end{array}$ & $\begin{array}{c}\text { The } 3^{\text {rd }} \\
\text { Military } \\
\text { Mapping } \\
\text { Survey of } \\
1869-1887\end{array}$ & $\begin{array}{c}\text { "Plan Director } \\
\text { de Tragere" }\end{array}$ & $\begin{array}{c}\text { Landsat 5 } \\
(1984)\end{array}$ & $\begin{array}{c}\text { Landsat 8 OLI } \\
(2017)\end{array}$ \\
\hline $\begin{array}{c}\text { Urban border } \\
\text { area }\left(\mathrm{km}^{2}\right)\end{array}$ & 1.2 & 2.6 & 3.14 & 3.6 & 13.72 & 20.48 \\
\hline $\begin{array}{c}\text { Forests } \\
\left(\mathrm{km}^{2}\right)\end{array}$ & 1.48 & 0.78 & 0.78 & 0.70 & 0.16 & 0.14 \\
\hline
\end{tabular}

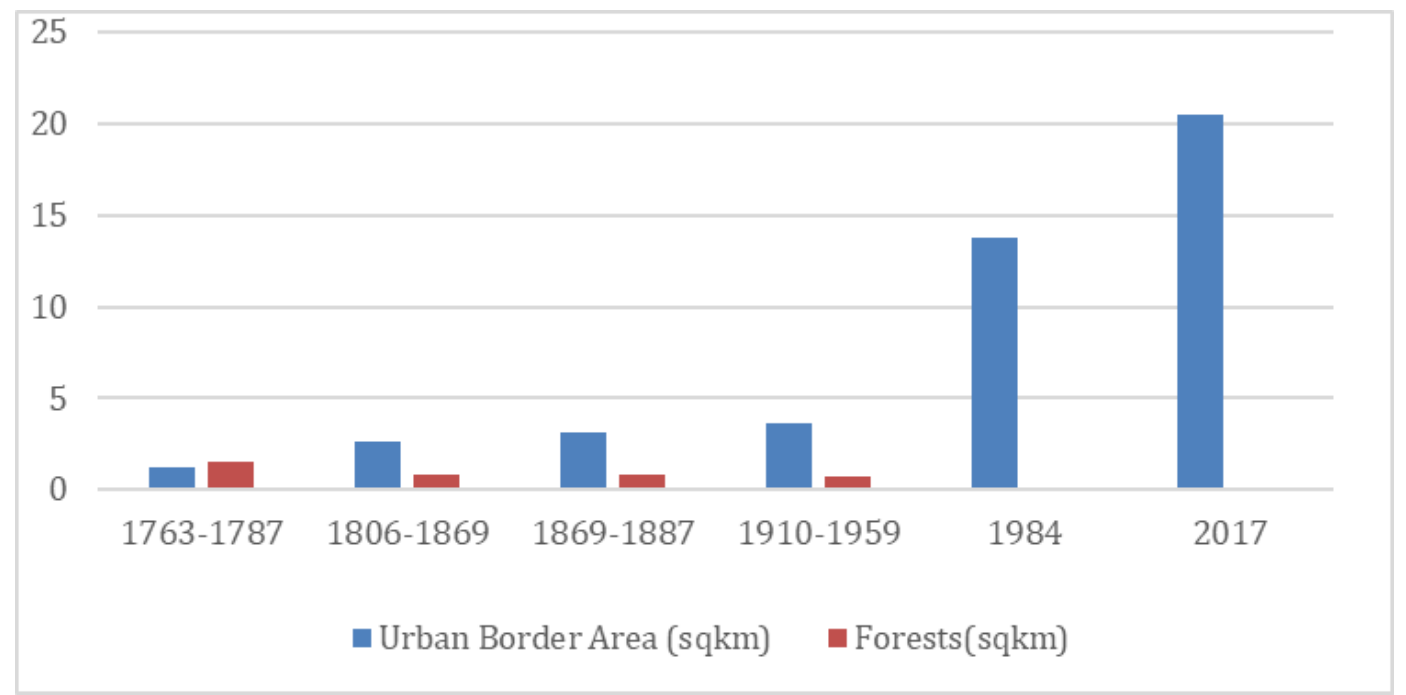

Figure 8. The evolution of the urban border area and of the forest lands between 1963 and 2017

The Someș River bed, due to several floods (which effects can be emphasized on the Military Survey's and on the "Plan Director de Tragere") diverged strongly, therefore, it was necessary to deviate or to drain some of the river arms. This represents an important directing factor of the urban sprawl. Between 1984 - 2017, we could observe a slight modification of the hydrography (a decrease of $4.17 \%$ of wetlands based on the change-detection method), due to the reorganized urban strategy of the city. The maximum deviation $(1.3 \mathrm{~km})$ can be observed by overlaying the $1^{\text {st }}$ Mapping Survey of Austria-Hungary with the Landsat 8 imagery from 2017. Therefore, we can conclude the fact that, this area is a highly dynamic surface from a hydrological point of view. 


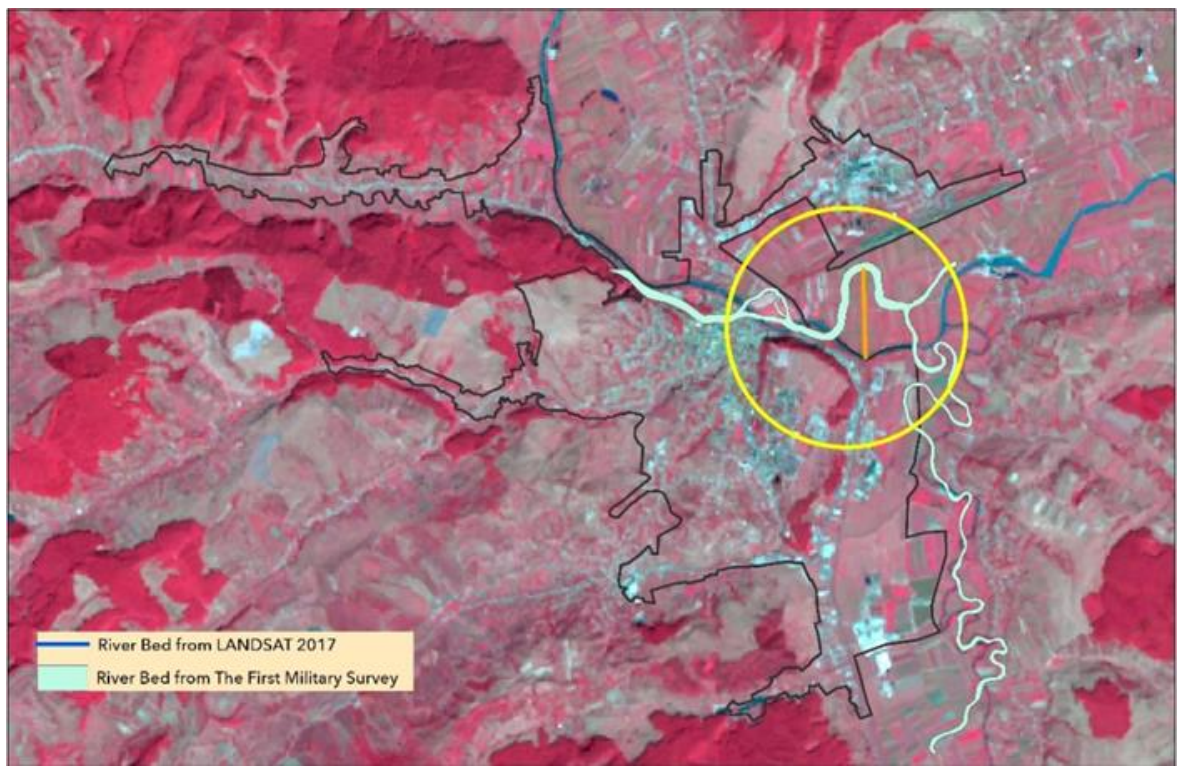

Figure 9. The maximum deviation of the Someș River bed

Observing the suburbanization tendency of the study area, we could calculate, according to Lakshmana, 1995, the future-land growth, by using geometrical weighted parameters, population and distance data of the neighbouring rural spaces. The followings are the formulas and the population and distance values that can be found in table 4 (the values were calculated using ArcGIS 10.5):

Future built-up land area $=($ Growth potential $x$ the area of the city in the present + the area of the city in the present)

Where:

$$
\begin{gathered}
\text { The growth potential }=\frac{\text { Weighted index potential }}{\text { Influence rate of built-up area }} \\
\text { Weighted index potential }=\frac{\text { EArea of potential } \mathrm{x} \text { distance between willage and city }}{\sum \text { Distance between willage and city }} \\
\text { Influence rate of built-up area }=\frac{\text { Circumference of city }}{\text { Area of city }}
\end{gathered}
$$

Table 4. The neighbouring villages and the distance between them and the city of Dej

\begin{tabular}{|c|c|c|c|c|c|c|c|}
\hline Village & Cetan & Urişor & Cuzdrioara & Mica & Codor & Mănăstirea & $\begin{array}{c}\text { Ocna } \\
\text { Dejului }\end{array}$ \\
\hline Distance & $7.5 \mathrm{~km}$ & $3 \mathrm{~km}$ & $4.5 \mathrm{~km}$ & $4 \mathrm{~km}$ & $3.8 \mathrm{~km}$ & $4.2 \mathrm{~km}$ & $3 \mathrm{~km}$ \\
\hline Surface & $0.92 \mathrm{~km}^{2}$ & $1.88 \mathrm{~km}^{2}$ & $1.973 \mathrm{~km}^{2}$ & $0.725 \mathrm{~km}^{2}$ & $1.35 \mathrm{~km}^{2}$ & $1.13 \mathrm{~km}^{2}$ & $2.855 \mathrm{~km}^{2}$ \\
\hline
\end{tabular}

Based on this formula, we calculated the future built-up land area of the city of Dej, which is $30.97 \mathrm{~km}^{2}$. This value represents an increase by $47 \%$, therefore, we can conclude the fact that, in the future, the villages will unite with the city, as a consequence of the suburbanization process. 


\section{DISCUSSIONS AND CONCLUSIONS}

Based on the results of this study, we can confirm that, the urbanization process has significantly modified the land-use between the 1763 and 2017 period. We successfully combined GIS and remote sensing techniques in order to calculate the rate and the tendency of land-use change, and the urban sprawl of the investigated area.

With the help of the historical maps, supervised classification and change-detection techniques, we could identify the factors that changed the land-use of the study area: in the $18^{\text {th }}$ century, due to the city's particular setting, Dej became a market town, therefore, the urban border area had grown by $116.66 \%$ and the forest lands decreased by $47.29 \%$; in 1881 , the railway infrastructure had developed, leading to the development of the city's economy, having, as consequence an increase of $20.76 \%$ urban area; after the Second World War, new industries appeared, therefore. population migration had begun and the urban border area has increased significantly by $281.11 \%$ and the forest lands had decreased dramatically by $82.05 \%$; after 1990 , the suburbanization process of the city has begun, caused by new political, social and economic contexts introduced in Romania; due to the economic loss and the attraction of the rural sites, the built-up area has increased by $13.85 \%$ in the S-SE and $\mathrm{N}$ direction, near the northern communication roads; the forest lands were characterized by stagnation. Using Lakshmana's formula, we could predict the fact that, in the future, the city of Dej will unite with the neighbouring villages, having a $47 \%$ built-up area increase.

The Someș River bed, due to several floods, changed drastically, therefore, it was necessary to deviate and drain some of the river's arms. Due to this fact, the urban sprawl has a south- southeast orientation, bypassing the river bed direction.

The information obtained with remote sensing and GIS techniques are essential in order to understand the causes of land-use change in the city of Dej, and can be used for further landplanning strategies and hazard mitigation works, in order to have a sustainable urban planning. Proper management of land-use is required, because if this does not exist, forest areas can't be restored, and land-degradation will appear due to the over-usage of the arable lands.

\section{REFERENCES}

Abd El-Kawy, O.R., Rod, J.K., Ismail, H.A., \& Suliman, A.S., (2011). Land use and land cover change detection in the western Nile delta of Egypt using remote sensing data. Applied Geography, 31, 483-494.

Benedek, J., \& Bagoly, P. (2005). Procesul de suburbanizare din România. Studiu de caz, zona suburbană a municipiului Târgu Mureş. Studia UBB, Geographia, L, 2, Cluj-Napoca.

Butt, A., Shabbir, R., Ahmad, S.S., \& Aziz, N. (2015). Land use change mapping and analysis using Remote Sensing and GIS: A case study of Simly watershed, Islamabad, Pakistan. The Egyptian Journal of Remote Sensing and Space Sciences, 18(2): 251-259.

Chowdhury, I. U. (2003). The role of RAJUK in planned urban development. In N. Islam (Ed.), World habitat day 2003: Souvenir on water and sanitation for cities, Dhaka. Bangladesh Institute of Planners and Center for Urban Studies, pp. 88-91.

Cohen, J. (1960). A coefficient of agreement for nominal scale. Educ Psychol Meas. 20, 37-46.

Congalton, R. G. (1991). A review of assessing the accuracy of classifications of remotely sensed data. Remote Sensing of Environment, 37(1): 35-46.

Dewan, M.A., \& Yamaguchi, Y. (2009). Land use and land cover change in Greater Dhaka, Bangladesh: Using remote sensing to promote sustainable urbanization. Applied Geography, 29, 390-401.

El Garouani, A., Mulla, D.J., El Garouani, S., \& Knight, J. (2017). Analysis of urban growth and sprawl from remote sensing data: Case of Fez, Morocco. International Journal of Sustainable Built Environment, 6(1), 160-169.

Fang, S., Gertner, G. Z., Sun, Z., \& Anderson, A. A. (2005). The impact of interactions in spatial simulation of the dynamics of urban sprawl. Landscape and Urban Planning, 73, 294-306.

Fichera, R.C., Modica, G., \& Pollino, M. (2017). Land Cover classification and change-detection analysis using multitemporal remote sensed imagery and landscape metrics. European Journal of remote sensing, 45(1), 1-18.

Foody, G.M. (2002). Status of land cover classification accuracy assessment. Remote Sensing of Environment, 80, $185-201$.

Gatrell, J.D., \& Jensen, R.R. (2008). Sociospatial applications of remote sensing in urban environments. Geography Compass, 2(3), 728-743.

Giri, C., Zhu, Z., \& Reed, B. (2005). A comparative analysis of the Global Land Cover 2000 and MODIS land cover data 
sets. Remote Sensing of Environment, 94, 123-132.

Hogland, J., Billor, N., \& Anderson, N. (2013). Comparison of standard maximum likelihood classification and polytomous logistic regression used in remote sensing. European Journal of Remote Sensing, 46(1), 623-640.

Ilovan, O.- R., \& Papp, L. (2007). Impact of The Industrial Activity on Demography in the Neighbouring Rural Area of Dej Municipium, Between 1930 and 2005. Geographia Napocensis, I, No. 1-2, 64-83.

Kasperson, J.X., Kasperson, R.E., \& Turner, B.L. (1995). Regions at Risks: Comparisons of Threatened Environments, UN University Press, Tokyo.

Lakshmana, R.K.M. (1995). Remote sensing for land-use planning. Int. J. Remote Sensing, 16(1), 53-60.

Li, H., Liu, Q. (2008). Comparison of NDBI and NDVI as indicators of surface urban heat island effect in MODIS imagery SPIE Vol. 7285 -728503-9.

Lillesand, T. M., \& Kiefer, R. W. (1994). Remote sensing and image interpretation (4 ${ }^{\text {th }}$ ed.), New York: Wiley.

Liu, C., Frazier, P., \& Kumar, L. (2007). Comparative assessment of the measures of thematic classification accuracy. Remote sensing of environment, 107(4), 606-616.

Lopez, E., Bocco, G., Mendoza, M., Duhau, E. (2001). Predicting land coverand land use change in the urban fringe a case in Morelia City, Mexico. Landscape and Urban Planning, 55(4), 271-285.

Lu, D., Mausel, P., Brondizio, E., \& Moran, E. (2004). Change detection techniques. International journal of remote sensing, 25(12), 2365-2401.

Lunetta, R. S., \& Elvidge, C. D. (1998). Remote sensing change detection, MI: Ann Arbor Press.

My, V.Ch., Lan, P.T, \& Son, T.S. (2009). Monitoring urban space expansion using Remote sensing data in Ha Long city, Quang Ninh province in VietNam. $7^{\text {th }}$ FIG Regional Conference Spatial Data Serving People: Land Governance and the Environment - Building the Capacity Hanoi, Vietnam, 19-22 October 2009.

Olofsson, P., Foody, G. M., Herold, M., Stehman, S. V., Woodcock, C. E., \& Wulder, M. A. (2014). Good practices for estimating area and assessing accuracy of land change. Remote Sensing of Environment, 148, $42-57$.

Ozesmi, S. L., \& Bauer, M. E. (2002). Satellite remote sensing of wetlands. Wetlands ecology and management, 10(5), 381-402.

Owojori, A., \& Xie, H. (2005). Landsat image-based LULC changes of San Antonio, Texas using Advanced atmospheric correction and Object-oriented image analysis Approaches. The $5^{\text {th }}$ International Symposium on Remote Sensing of Urban Areas, Tempe, AZ.

Rawat, J.S., \& Kumar, M. (2015). Monitoring land use/cover change using remote sensing and GIS techniques: A case study of Hawalbagh block, district Almora, Uttarakhand, India. The Egyptian Journal of Remote Sensing and Space Sciences, 18, 77-84.

Reis, S. (2008). Analyzing Land Use/Land Cover Changes Using Remote Sensing and GIS in Rize, North-East Turkey. Sensors, 8, 6188-6202.

Rogan, J., \& Chen, D. (2004). Remote sensing technology for mapping and monitoring land-cover and land-use change. Progress in Planning, 61, 301-325.

Roy, D. P., Lewis, P.E., Justice, C.O. (2002). Burned area mapping using multi-temporal moderate spatial resolution data a bi-directional reflectance model-based expectation approach. Remote Sensing of Environment, 83, $263-286$.

Rüsz Fogarasi, Enikö (2003). Dejul medieval, între oraşşsi târg, pp. 313-319, în Tentaţia istoriei, Bocşan, N., Ghita, O., Radosav, D. coordonatori, Editura Presa Universitară Clujeană, Cluj-Napoca.

Shalaby, A., \& Tateishi, R. (2007). Remote sensing and GIS for mapping and monitoring land cover and land-use changes in the Northwestern coastal zone of Egypt. Applied Geography, 27(1), 28-41.

Stefanov, W. L., Ramsey, M. S., \& Christensen, P. R. (2001). Monitoring urban land cover change: An expert system approach to land cover classification of semiarid to arid urban centers. Remote sensing of Environment, 77(2), 173-185.

Warner, T.A., \& Campagna, D.J. (2009). Remote sensing with IDRISI Taiga: A beginner's guide., Hong Kong, Geocarto International Centre.

Xiao, J., Shen, Y., Ge, J., Tateishi, R., Tang, Ch., Liang,Y., Huang, Z. (2006). Evaluating urban expansion and land use change in Shijiazhuang, China, by using GIS and remote sensing. Landscape and Urban Planning, 75, 69-80.

Yuan, F., Sawaya, K. E., Loeffelholz, B. C., \& Bauer, M. E. (2005). Land cover classification and change analysis of the Twin Cities (Minnesota) Metropolitan Area by multitemporal Landsat remote sensing. Remote sensing of Environment, 98(2-3), 317-328.

*** www.mapire.hu

$* * *$ https://www.usgs.gov/

*** Plan Urbanistic General al Municipiului Dej, Memoriu General, 2005, source: http://www.primariadej.ro/uploads/Documente/PUG/PARTE\%20SCRISA/Memoriu\%20PUG\%20DEJ.pdf, accessed 08.12.2018.

*** Recensământul general al populaţiei 2011, date preliminare, Comisia Naţională pentru Statistică, Bucureşti http://www.recensamantromania.ro/rezultate-2/ accesed 08.12.2018.

*** Vasile Crăciunescu, Ioan Rus, Ștefan Constantinescu, Ionuț Ovejanu, Zsombor Bartos-Elekes (2011) Romanian maps under 'Lambert-Cholesky' (1916-1959) projection system, www.geo-spatial.org/download/planurile-directoarede-tragere?lang=en, accesed 08.12.2018.

Submitted:

September 20, 2018
Revised:

June 20, 2019
Accepted and published online

August 09, 2019 